\title{
APICAL DISPLACEMENT PRODUCED BY ROTARY NICKEL-TITANIUM INSTRUMENTS AND STAINLESS STEEL FILES
}

\author{
DESLOCAMENTO APICAL PRODUZIDO POR INSTRUMENTOS DE NÍQUEL- \\ TITÂNIO ACIONADOS A MOTOR E LIMAS DE AÇO INOXIDÁVEL
}

\author{
José Roberto VANNI, PhD \\ Senior Professor of Endodontics - FOUPF - Student in Endodontics - UPE. \\ Diana Santana de ALBUQUERQUE, PhD \\ Professor of the Post-Graduation Programs in Endodontics - UPE (Master and Doctorate programs). \\ Cristina REISS, PhD \\ Professor of Endodontics of the State University of Feira de Santana. Student in Endodontics - UPE.

\section{Flares BARATTO FILHO, PhD} \\ Professor of Endodontics at the Dental School of Joinville. Student in Endodontics - UPE.

\section{Orlando LIMONGI, PhD} \\ Professor of Endodontics at ULBRA - Canoas. Student in Endodontics - UPE.

\section{Álvaro DELLA BONA, PhD} \\ Professor of Prosthodontics and Occlusion - FOUPF.
}

\begin{abstract}
$T$ he aim of this study was to evaluate the apical displacement produced by different rotary nickel-titanium instruments, testing the hypothesis that rotary systems with nickel-titanium instruments produce lower mean values of apical displacement than stainless steel hand instruments. A total of 100 maxillary permanent first molars were selected for the study. The mesiobuccal roots were sectioned at the top cervical third and embedded in blocks of self-curing resin. The specimens were randomly divided into 5 groups and the root canals were prepared using the following nickel-titanium instruments: Group 1 - Quantec system 2000 (Analytic Endodontics, Mexico); Group 2 - Pro-File T.0.04 (Dentsply/Maillefer, Switzerland); Group 3-Pro-File Series 29 T.0.04 (Dentsply Tulsa, Switzerland); Group 4 - Pow-R T.0.02 (Moyco-Union Broach, USA). Specimens in Group 5 were prepared using stainless steel hand instruments Flexofile (Dentsply/Maillefer, Switzerland). All root canals were previously submitted to cervical preparation using Orifice Shaper instruments \#1, 2, 3 and 4 (Dentsply/Maillefer, Switzerland). After odontometry, the remaining root canal was shaped employing increasingly larger instruments, so that the final instrument corresponded to Quantec \#9, Pro-File Series 29 \#6, and \#35 for the other groups. Specimens in Groups 1 to 4 were prepared using an electric handpiece with 16:1 reduction at $350 \mathrm{rpm}$. The specimens in Group 5 were manually prepared. Apical displacement was measured and recorded by means of radiographic superimposition on a specific desk. Statistical analysis (ANOVA) of the results revealed that all groups presented apical displacements. Considering only the nickel-titanium instruments, Group 4 showed the lowest mean value while Groups 2 and 3 produced the highest mean apical displacement values $(\mathrm{p}<0.001)$.
\end{abstract}

UNITERMS: Nickel-titanium instruments; Rotary systems; Apical displacement; Stainless steel files. 


\section{INTRODUCTION}

Preparation of the root canal comprises a chemical and a mechanical stage, aiming at the achievement of biological goals in the endodontic treatment. During the mechanical stage, procedures are accomplished for cleaning, canal walls planing, and root canal shaping, to achieve a continuous conical shape and preserving the original dimension and position of the tooth apex.

Continuous and improper movements of stainless steel endodontic instruments may yield alterations in the position and shape of the tooth apex. Such shortcoming is observed more frequently when these instruments are manually applied with increasing widths throughout the working length. The increased possibility of apical deformation is directly proportional to the severity of the root curvature (Tang, Stock $\left.{ }^{10}, 1989\right)$.

Much emphasis has been given to improve the flexibility of endodontic instruments through the employment of different alloys for their production. Thus, the nickel-titanium instruments are up to five times more flexible than the stainless instruments and their efficacy in keeping the original position of the root canal apex has been demonstrated by several investigators (Felippe, Felippe, Alves², 2003; Leonardo, Leonardo $^{3}, 2002$ e Lopes, et al. ${ }^{4}$, 1997).

The dental practitioner often faces the need to shape a root canal with different degrees of curvature in the daily practice. The professional decides to employ nickel-titanium endodontic instruments considering these curvatures and because of the wish to prepare the root canal as fast and safe as possible with the least physical effort. Due to the higher flexibility of these instruments, there is a better chance to keep the tooth apex on its original position, thus reducing the possibility of an unsuccessful endodontic therapy. This new generation of endodontic instruments presents higher resistance to fracture in clockwise and counterclockwise directions, good biocompatibility, high resistance to corrosion, and no deformation when submitted to sterilization procedures (Mayhew, Kusy ${ }^{5}$, 1985). They also demonstrate two significantly important properties from a clinical standpoint, namely: the shape memory effect and the superelasticity (Serene, Adams, Saxena ${ }^{6}$, 1995).

The concept of progressive enlargement is considered a basic principle of the endodontic therapy. Nickel-titanium instruments are produced with variable tapers in order to favor this principle and allow a more adequate enlargement of the cervical and middle thirds with less extrusion of debris towards the periapex (Sydney ${ }^{8}$, 1997).

Many of these properties have already been evaluated, especially in comparative studies with stainless steel instruments, which demonstrated their real value and justified their use for preparation of root canals with anatomical complications (Carvalho, Bonetti, Borges ${ }^{1}$, 1999).

The current technological status also allowed significant alterations in the morphology of nickel-titanium instruments, such as: the achievement of blunt tip instruments; the modifications in the dentin cutting ability by alterations in the cutting angle; and, especially, the changes in the fabrication method, which is now performed by machining.

All these factors contributed to allow the use of endodontic instruments by means of an electric engine. These rotary systems may currently be regarded as a promising technology in the daily endodontic practice, and many of them are already commercially available (Leonardo, Leonardo ${ }^{3}$ 2002). The electric engines allow constant speed following the manufacturer recommendations, besides the possibility of associating a solution container that allows constant irrigation during preparation of the root canal (Sydney, et al. ${ }^{9}$ 2001).

Despite of the remarkable support to this issue in the literature, there are few studies about the performance of these automated systems, especially as to the possibility of apical deformation while shaping root canals presenting curvatures or atresia.

Therefore, the aim of this study was to compare the apical displacement produced by four different rotary systems using nickel-titanium endodontic instruments during preparation of the root canals of mesiobuccal roots of maxillary first molars, testing the hypothesis that systems using nickel-titanium instruments produce lower mean apical displacement values than the system employing stainless steel hand instruments.

\section{MATERIALSAND METHODS}

A total of 100 permanent maxillary first molars were selected for this study. The teeth were stored in a $0.5 \%$ chloramine solution at the tooth bank of the University of Passo Fundo, Dental School, which is controlled by the Research and Ethics Committee of the same University. The mesiobuccal roots were sectioned from teeth at the top cervical third and embedded in blocks of self-curing resin. The teeth remains were excluded from this study and returned to the tooth bank.

The specimens were divided into 5 groups according to the following systems used to prepare the root canals: Group 1, Quantec 2000 system (Analytic Endodontics, Mexico); Group 2, Pro-File 0.04 taper (Dentsply/Maillefer, Switzerland); Group 3, Pro-File series 290.04 taper (Dentsply/Tulsa, Switzerland); Group 4, Pow-R 0.02 taper (Moyco-Union Broach, USA) - all these are nickel-titanium instruments; and Group 5, Flexofile stainless steel hand files (Maillefer, Switzerland). All roots were previously submitted to cervical preparation using Orifice Shaper instruments \#1, 2, 3 and 4 (Maillefer, Switzerland). The odontometry was performed through the Cohen's method with a \#15 Flexofile file (Maillefer, Switzerland), 1mm from the radiographic apex of each specimen. The radiographic films used in this study were the Ultra Speed (Kodak Company, USA), which were exposed for $0.5 \mathrm{~s}$ and developed according to the time/ temperature method.

A radiographic desk was fabricated (Sydney, Batista, Melo $\left.^{7}, 1991\right)$ and attached to the cylinder of the X-ray machine (Spectro II $60 \mathrm{HZ}$, Dabi Atlante, Brazil) to avoid 
differences in the angulations employed for each specimen, therefore allowing standardization of the position of the cylinder in relation to the object and film.

The root canals were shaped using increasingly larger instruments, so that the final instrument employed for preparation of the entire working length corresponded to Quantec 2000 \#9 (Analytic Endodontics, Mexico), \#6 for series 29 and \#35 for the other groups, including Group 5. The irrigant used was $1 \%$ sodium hypochlorite (Formula \& Acao, Brazil), with a volume of $10 \mathrm{ml}$ for each specimen.

Preparation of the root canals for Groups 1 to 4 was performed by means of an electric handpiece with 16:1 reduction at $350 \mathrm{rpm}$ (Nouvag TCM Endo, Switzerland). Manual preparation was accomplished on Group 5 by means of the step-down technique.

The same operator, a specialist in Endodontics, performed both the mechanical and manual preparations.

The apical displacements produced by the endodontic instrument were measured superimposing the odontometry and final preparation radiographs, which were projected with a 20X magnification on a white paper, where a tangent was traced uniting the tip of both instruments in case there was displacement. Finally, the separation between the two points, corresponding to the displacement, was measured by a 0.05mm precision caliper (Mitutoyo, Japan) (Lopes, et al. ${ }^{4}$, 1997).

For statistical purposes, descriptive statistics using the F-test and one-way analysis of variance (ANOVA) with 5 levels (or 5 groups) were used. Differences in mean values were analyzed using the Tukey test for multiple comparisons.

It should be noted that, for application of the ANOVA, the distances were initially transformed by means of square root, in order to verify the hypotheses of equality of variance (homogeneity of variance) and normality of the data.

Verification of the hypothesis of normality of the data was performed by the Shapiro-Wilks test and for the equality of variance Levene's test was used, which are required for application of the ANOVA (SPSS version 11.0 - Statistical Package for the Social Sciences).

A significance level of $5 \%$ was employed for all statistical tests.

\section{RESULTS}

The group mean and standard deviation values, and the coefficient of variation of the displacement, according to the instrument system employed are presented in Table 1. Results show that the lowest mean apical displacement value was found for the Pow-R system (Group 4), and the highest value was found for the hand system. The highest transformed coefficient of variation was $21.99 \%$, for Group 4 (Table 1).

ANOVA and Tukey tests showed statistically significant differences between all group mean values ( $<<0.001)$, except between Groups 2 and 3. The manually prepared Group 5 exhibited higher mean apical displacement values than all other groups.

\section{DISCUSSION}

The nickel-titanium endodontic instruments were introduced by Walia, et al. in 1988. Made out of such alloy, the instruments present two improved fundamental

TABLE 1- Group mean and standard deviation apical displacement values ( $\mathrm{mm})$, and the coefficient of variation of the displacement (\%), according to the instrument system employed

Instrument systems

\begin{tabular}{|c|c|c|c|c|c|c|c|c|c|c|}
\hline \multirow[t]{2}{*}{ Outcomes } & \multicolumn{2}{|c|}{$\begin{array}{l}\text { Group } 1 \\
\text { Quantec }\end{array}$} & \multicolumn{2}{|c|}{$\begin{array}{c}\text { Group } 2 \\
\text { Pro-file Maillefer }\end{array}$} & \multicolumn{2}{|c|}{$\begin{array}{c}\text { Group } 3 \\
\text { Pro-file Tulsa }\end{array}$} & \multicolumn{2}{|c|}{$\begin{array}{l}\text { Group } 4 \\
\text { Pow-R }\end{array}$} & \multicolumn{2}{|c|}{$\begin{array}{l}\text { Group } 5 \\
\text { Hand files }\end{array}$} \\
\hline & Displ* & $\mathrm{Sq}^{\star *}$ & Displ* & $\mathrm{Sq}^{\star \star}$ & Displ* & $\mathrm{Sq}^{\star \star}$ & Displ* & $\mathrm{Sq}^{\star \star}$ & Displ* & $\mathrm{Sq}^{\star \star}$ \\
\hline Mean ${ }^{(1)}$ & $0.16^{(\mathrm{B})}$ & 0.39 & $0.21^{(\mathrm{c})}$ & 0.45 & $0.21^{(\mathrm{c})}$ & 0.46 & $0.10^{(\mathrm{A})}$ & 0.31 & $0.50^{(\mathrm{D})}$ & 0.70 \\
\hline $\begin{array}{l}\text { Standard } \\
\text { deviation }^{(1)}\end{array}$ & 0.07 & 0.08 & 0.06 & 0.07 & 0.06 & 0.07 & 0.04 & 0.07 & 0.11 & 0.08 \\
\hline $\begin{array}{l}\text { Coefficient of } \\
\text { variation }^{(2)}\end{array}$ & 41.31 & 20.82 & 30.55 & 15.93 & 29.44 & 15.43 & 42.92 & 21.99 & 22.48 & 11.45 \\
\hline
\end{tabular}

(1) - Values are in $\mathrm{mm}$.

(2) - Percent values.

* Displacement

** Square of the distance of displacement

Note - Different letters in parentheses indicate a statistically significant difference between the pairs of groups. 
properties: elasticity and the shape memory effect, which allow a better fitting to the different curvatures of the root canal, therefore providing shaping with less risk of deformation.

In addition to the properties of nickel-titanium instruments, the rotary systems were introduced in Dentistry for preparation of the root canals, with special emphasis to the ones presenting continuous motion controlled by an electric engine. The great advantage of the automated systems is the faster preparation of the root canal, especially in the presence of curvatures and atresia, besides reduction in the operator's stress. The selection of mesiobuccal roots of maxillary molars for this study is based on the high incidence of curvatures or atresia in this type of root canal.

During preparation of the root canal, the endodontists are concerned about performing it safely, with no risk of accidents and keeping the canal within its original shape. Therefore, the objective of this study was to examine the amount of apical displacement produced by an automated handpiece with continuous motion using different types of nickel-titanium instruments.

The technique for preparation followed the Crown-Down principle, which is required for the automated preparation. The application of orifice-shaper instruments \#1, 2, 3 and 4 provided enlargement of the cervical third with less tension on the instruments to be tested, favoring the accomplishment of a similar work on the middle and apical thirds of the root canal.

When Groups 2 and 3 (Pro-File Maillefer and Pro-File Tulsa) were compared to Group 1 (Quantec 2000), the displacement was statistically significant lower for the latter, demonstrating a more stable action of the Quantec system on the apical third, which may be due to the taper variance present on these instrument systems.

Statistically significant differences were also observed between Groups 1 (Quantec 2000) and 4 (Pow-R). The Pow$\mathrm{R}$ system showed the lowest apical displacement values, probably due to the constant tapering instrument system, which presents a taper of 0.02, whereas the Quantec system also includes tapers of 0.04 and 0.06 in addition to 0.02 .

Finally, concerning the comparison of Groups 2 (ProFile Tulsa) and 3 (Pro-File Maillefer-Dentsply) with Group 4 (Pow-R), there was significant less apical displacement for the latter, which also could be due to the constant 0.02 taper of all instruments in the Pow-R system.

This study suggests that, despite of the previous cervical preparation with orifice-shapers instruments, the degree of taper of the different instrument systems has an effect on the presence of apical displacement, since the best mean value was found for Group 4 (Pow-R) that has the lowest and constant taper instruments of all systems evaluated.

The entire series of instruments was employed for Group 1 (Quantec), which implies variations in size and taper. For example, instrument \#8 has a similar width at the tip as instrument \#25 of the ISO series, yet with 0.06 taper. On the other hand, the instrument \#9, which corresponds to the instrument \#40 of the ISO series, has a taper of 0.02 . Yet, the results suggest that the combination of width and taper present in the instruments of this system contributed to the good outcome, compared with the results produced by the Pro-File systems with constant 0.04 taper instruments.

Considering only the nickel-titanium instrument systems, the Pro-File systems, both from Tulsa and from Maillefer-Dentsply, presented the highest mean apical displacement values in the present study. This suggests that the constant 0.04 taper could be the dominant factor for this worst performance.

Finally, Group 5, which employed manual preparation with stainless steel files and previous cervical preparation, showed the highest mean apical displacement value that is statistically significant different from all others, which is in agreement with the literature. (Serene, et al. ${ }^{6}, 1995$; Sydney ${ }^{7}$, 1997; Leonardo ${ }^{3}$, 2002)

\section{CONCLUSIONS}

On the basis of the results revealed by this in vitro study, the following can be concluded:

- The Pow-R system presented the lowest mean apical displacement value compared to the other systems evaluated.

- The Quantec 2000 system presented a higher mean apical displacement value than the Pow-R system, yet a lower mean value in relation to the other experimental groups. The highest mean apical displacement values among the nickel-titanium instruments were found for the Pro-File groups, both from Maillefer and from Tulsa.

- Group 5, using stainless steel hand files showed the worst results for apical displacement.

- The initial hypothesis was confirmed, meaning that the rotary systems using nickel-titanium instruments produced lower mean apical displacement values than the stainless steel hand files.

\section{RESUMO}

O objetivo deste trabalho foi avaliar o deslocamento apical produzido por diferentes instrumentos de níqueltitânio acionadas a motor testando a hipótese de que os sistemas rotatórios que usam instrumentos de níquel-titânio produzem valores médios de deslocamento apical menores que as limas manuais de aço inox. Foram utilizados 100 primeiros molares permanentes superiores, cujas raízes mesiovestibulares foram separadas e incluídas em blocos de resina autopolimerizável. Os corpos de prova foram divididos aleatoriamente em 5 grupos e os canais radiculares preparados com instrumentos de níquel-titânio: Grupo 1 sistema Quantec 2000 (Analytic Endodontics, México); Grupo 2 - Pro-File T.0.04 (Dentsply/Maillefer, Suíça); Grupo 3 - Pro-File Série 29 T.0.04 (Dentsply Tulsa, Suíça); Grupo 4 - Pow-R T.0.02 (Moyco-Union Broach, EUA); e Grupo 5 (limas manuais) - limas manuais de aço inox Flexofile (Dentsply/Maillefer, Suíça). Todos os canais mesiovestibulares foram submetidos a um preparo cervical 
prévio utilizando-se instrumentos Orifice Shaper números 1, 2, 3 e 4 (Dentsply/Maillefer, Suíça). Realizada a odontometria, o restante do canal radicular foi modelado a partir dos instrumentos do menor para o maior calibre de tal ordem que o instrumento final de preparo correspondeu ao número 9 para o Quantec, número 06 para o Pro-File Série 29 e o número 35 para os demais grupos. Nos grupos de 1 a 4 foi utilizado motor elétrico com contra-ângulo de redução de 16:1 numa velocidade de 350 rpm. No grupo 5 o preparo foi realizado manualmente. A análise dos resultados (ANOVA), obtidos pela sobreposição radiográfica numa plataforma especifica, demonstraram que todos os grupos apresentaram deslocamentos apicais, sendo que o menor valor médio foi verificado no grupo 4 e os maiores valores médios foram observados nos grupos 2 e 3 ( $p<0,001)$.

UNITERMOS: Instrumentos de níquel-titânio; Sistemas rotatórios; Deslocamento apical; Limas de aço inoxidável.

\section{REFERENCES}

1- Carvalho LAP, Bonetti I, Borges MAGA. Comparison of molar root canal preparation using stainless steel and niquel titanium instruments. J Endodon 1999; 25:807-10.

2- Felippe WT, Felippe MCS, Alves AMH. Preparo manual de canais curvos. Odontologia Arte e Conhecimento 2003; 1:135-46.

3- Leonardo MR, Leonardo RT. Da estandartização aos instrumentos rotatórios: o que mudou? Endodontia - Trauma 2002; 2:3-14.

4- Lopes HP, Elias CN, Estrela C, Siqueira Jr. J, Fontes PP. Influência de limas endodônticas de NiTi e de aço inoxidável, manuais e acionadas a motor no deslocamento apical. Rev Bras Odontol 1997; 54:67-70.

5- Mayhew MJ, Kusy RP. Effects of sterilization on the mechanical properties and the surface topography of the nickel-titanium arch wire. Am J Orthod Dentofacial Orthop 1985; 93:232-6.

6- Serene TP, Adams JD, Saxena A. Nichel-titanium instruments applications in endodontics. Saint Loius: Ishiyaku Euroamericana, 1995, p.112.

7- Sydney GB, Batista A, Mello LL. The radiographic platform: a new method to evaluate root canal preparation. J Endod 1991; 17(11): 570-2.

8- Sydney GB. Instrumentos de níquel-titânio: Análise do preparo do canal radicular realizado manual e mecanicamente. Curitiba: 1997. [Tese Professor Titular - Universidade Federal do Paraná].

9- Sydney GB, Zamberlan TMA, Batista A, Mello LL. Estudo comparativo da ocorrência de desvio apical com sistemas de rotação alternada. JBE 2001; 2:246-52.

10- Tang MPF, Stock CJR. An in vitro method for comparing the effects of diferents root canal preparation techniques on the shape of curved root canals. Int Endod J 1989; 22:49-54.
11- Walia H, Brantley WA, Gerstein H. An initial investigation of the bending and torsional properties of a Nitinol root canal files. $\mathrm{J}$ Endodon 1988; 14:346-51.

Recebido para publicação: 05/08/2003

Enviado para reformulações: 12/09/2003

Pronto para publicação: 20/10/2003

\author{
Correspondence to: \\ José Roberto Vanni \\ Rua Bento Gonçalves, 50 - Conj. 801 \\ 99010-013 - Passo Fundo - RS \\ Telefone: (54) 313-6155 \\ E-mail: jrvanni@bol.com.br
}

